\title{
Employability through Experiential Learning Course in Open Distance Learning Institution
}

\author{
Tshilidzi Eric Nenzhelele \\ Senior Lecturer, University of South Africa \\ Email address: nenzhte@unisa.ac.za
}

\section{Doi:10.5901/mjss.2014.v5n20p1602}

\section{Abstract}

The supply of business and management (B\&M) graduates to the labour market has grown significantly. One wanders if these graduates are employable. Employability is of high importance not only for unemployed or laid off individuals, but also for those who are currently employed in today's turbulent work environment. It is a responsibility of high education institution to produce graduates with employability skills. There is a gap between skill requirements for entry-level graduate employment and those offered by high education institutions. Experiential learning has been suggested as a learning method to reduce the skills gap. However, not all experiential learning courses equip learners with employability skills. It is therefore important to evaluate the influence of a course on employability. The purpose of this research is to establish the influence of a work-integrated learning course in administrative management on employability. The research establishes that experiential learning influence employability to a greater extent. This research reveals the value of experiential learning in business management in open distance learning institution.

Keywords: Employability; Employability skills; Experiential learning; Open Distance Learning

\section{Introduction}

The major reason people register at universities is to graduate and get employment (Gokuladas, 2011). Universities must therefore equip graduates with employability skills (Wittekind, Raeder \& Grote, 2010). While universities around the world are producing so many graduates; most of them struggle to get a job (Wickramasinghe \& Perera, 2010). This is because there is a gap between acquired skills and skills required by employers (Nilsson, 2010). Experiential Learning (EL) has been suggested as a learning method to reduce the skills gap (Procter, 2011). While research on EL and employability has been conducted extensively on engineering; agricultural science; teacher education; nursing education; medical education; and law, it is rare in business management field (Arnold, Warner \& Osborne, 2006). Moreover, research conducted on EL and employability has been based on conventional educational institutions and not on open distance learning institutions (Procter, 2011). Therefore, the purpose of this study is to establish the influence of EL course in administrative management in open distance learning on employability. The objectives of this research are: to establish whether studying an EL course in business management leads to employability and to establish the influence of different students' demographics on employability. The results of this research will reveal to educational institutional particularly open distance learning the value of incorporating EL in their courses.

In the sections that follow, existing literature is outlined. This is followed by a discussion of the research design. The results of this research are discussed thereafter followed by ethical consideration, trustworthiness, discussion and acknowledgements.

\section{Literature Review}

\subsection{Experiential learning}

True learning is the result of students' experiences, and the evaluation and reflection of these experiences (Moore, Boyd \& Dooley, 2010). EL unlocks capabilities because it is about action rather than learning theory (Jennings \& Wargneir, 2010). Ghose (2010) states that EL can be implemented by educators in varied disciplines to equip students with hand-on experience. Clark and White (2010) conclude that quality university business education program must include an EL component. 
Although there are many definitions of EL, Kolb (1984) is the most quoted. Kolb (1984) defines EL as the process whereby knowledge is created through the transformation of experience. According to Kolb, EL is a four stage process. These stages are depicted in figure 1 and discussed below.

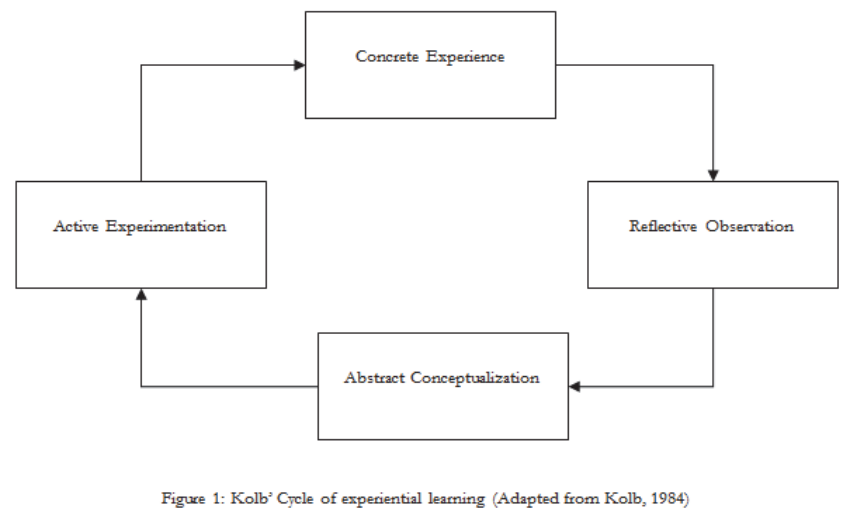

- Concrete Experience: the learner must be willing and be actively involved in the experience;

- Reflective Observation: the learner must be able to reflect on the experience;

- Abstract Conceptualization: the learner must possess and use analytical skills to conceptualize the experience; and

- Active Experimentation: the learner must possess decision making and problem solving skills in order to use the new ideas gained from the experience.

EL is categorized into two types: one which is more personal and informal and one that is a designed learning event with situations to which the learner is intentionally exposed (Vesper, Kartog, Bishara \& Reeves, 2010). EL can take many forms including internships, volunteering to work in a firm and simulation (Clark \& White, 2010).

EL provides many benefits to students, faculties and educational institutions, enterprises, researchers and government policy makers (Hynes \& Richardson, 2007). According to Nevin (2001) EL provide learners with fun, exciting and entertaining way of learning. EL gives students an opportunity to be real not pretenders (Vincett \& Farlow, 2008). In addition, EL create the right atmosphere for learning, put value on students' knowledge, skills and experience, enforce sharing of ideas and increase synergistic learning of participants (Smith, Collins \& Hannon, 2006).

\subsection{Experiential learning at the University of South Africa}

The course is entitled "Administrative Practice" because of the EL component in it. This course is offered by the University of South Africa (UNISA) the largest Open Distance Learning (ODL) university in Africa. The purpose of the course is to provide the learners with EL in the national diploma in administrative management. This course prepares students for the work environment.

Upon registration, students receive study materials which include all assignments to be completed. One of the assignments they must complete is the EL project which should be completed in a work environment and submitted to the university for final assessment. Other assignments cover theory on EL. With the help of the university, students are to find a work placement. They are required to spend two months at the work environment. During this period, students are to familiarise themselves with the organisation in which they are placed; learn the information systems in use; use both written and electronic communication; discover the area that require insurance; plan the office environment; learn how administrative function support other organisational functions; learn about quality assurance; ensure that the office observes green principles; expose themselves to facilities management; learn about automated processes in the organisation; learn about ergonomic office; discover how the organisation decorate its offices; learn about buying; and facilitate meetings. In a nutshell, students learn all about administrative management.

Students are provided with a log book which contains all the activities they should complete. After completing each activity, students must record evidence of completion in a portfolio of evidence. They are required to attach supporting documents to their portfolio. Also, students are to declare ownership of their portfolio of evidence by attaching a 
declaration form with a stamp of commissioner of auth. They are to make their portfolio presentable by biding or filing it and get it ready for submission to the university. The portfolio is submitted towards the end of the year for final assessment.

\subsection{Employability}

Employability is of high importance not only for unemployed or laid off individuals, but also for those who are currently employed (Wittekind, Raeder \& Grote, 2010). Moreover, employability skills enable graduates to progress in their careers both personally and also within the organisations they work (Wilton, 2011). Highly employable workers enable organizations to meet fluctuating demands for new products and services (Nauta, Van Vianen, Van der Heijden, Van Dam \& Willemsen, 2009).

According to Wilton (2011), the supply of business and management graduates to the labour market has grown significantly. However, employability has increasingly become a concern of students, employers and governments (Arrowsmith, Bagoly-simo, Finchum, Oda \& Pawson, 2011). Employability is the prime factor that influences the very thoughts of a graduating student (Gokuladas, 2011). On the other hand, employability is an important requirement, both for organizations that need to compete in a changing environment and for individuals who aim for career success (Van der Heijde \& Van der Heijden, 2006). For these reasons, majority of higher learning institutions provide training with EL to equip students with necessary employability skills.

Although there are several definitions of employability, they focus on the personal attributes, understandings and attainments that make individuals more likely to gain and maintain employment, and to progress in workplaces and build careers (Watton \& Truscott, 2006). Little (2004) defines employability as a set of achievements, understandings, and personal attributes that make individuals more likely to gain employment and be successful in their chosen occupations. This is a detailed definition and it reveals how one becomes employable. In addition, this definition emphasise the fact that the individual should also be successful in their chosen career. Van der Heijde and Van der Heijden (2006) define employability as the continuous fulfilling, acquiring or creating of work through the optimal use of competencies. This definition incorporates sustainability of employment. This means that the individual does not only get employed but keeps his/her employment. Yorke and Knight (2004) define employability is a set of achievements - skills, understandings and personal attributes - that make graduates more likely to gain employment and be successful in their chosen occupations, which benefits themselves, the workforce, the community and the economy. This is a very broad and inclusive definition of employability. It reveals that the individual must accumulate certain skills in order to be employable and succeed in the chosen career path. Moreover, Yorke and Knight's (2004) definition indicate that the success of the individual with employability skills must benefit the workforce, community and economy.

There are three types of employability (Rothwell, Jewell \& Hardie, 2009). These are discussed below and their relationships are depicted in figure 2.

1) Employability of workforce: related to government policy or national-level 'skills' agendas, or at an industry Level. This perspective is derived from concerns about the changing nature of work and employment at the end of the 20th century.

2) Employability as human resource strategy: this relates to the notion of employability based on skills and personal flexibility acquired through employment, often promoted by employers as an alternative to job security.

3) Employability of individuals: largely derived from employability being flagged as a concern. Related to this were concerns about the ability of the university sector to provide graduates with the skills employers need, with the consequences of mass expansion of the university sector and linked to perceptions of significant changes in the wider labour markets. 


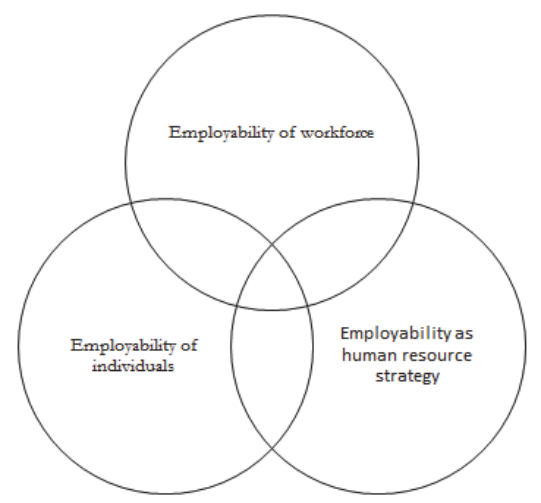

Figure 2: Types of employability and their relationship (Adapted from Rothwell, Jewell \& Hardie (2009)

Employability contains different dimensions such as the actual competence of the individual, formal qualifications gained through educational activities, hard technical vocational employability skills, and soft skills, including transferable metacompetence, interpersonal skills (Nilsson, 2010). According to Cox and King (2006), there are two aspects of employability, namely subject skills and transferable skills. Transferable skills refer to certain personal abilities of an individual, which can be taken from one job role to another, used within any profession and at any stage of his/her career while subject skills are more relevant to ones career.

Employability skills are skills needed for life-long learning and a successful business career (Stoner \& Milner, 2010). Employability skills are teachable skills and may be taught in both schools and employment settings. Therefore, the authority should set goals and objectives for teaching employability skills (Nayan, 2010). According to Nayan (2010), employability skills are categorized by the following competency areas: personal values, problem-solving and decisionmaking skills, relations with other people, communication skills, task-related skills, maturity, health and safety habits, and commitment to job. Wilton (2011) identified the following employability skills for business and management graduates: Written communication; ability to work in teams; research skills; basic computer literacy; spoken communication; problem-solving skills; numeracy skills; management skills; leadership skills; creativity; entrepreneurial skills; and advanced IT or software skills. These employability skills will be the basis for this research.

\subsection{Open distance learning}

There has been a tremendous growth of ODL institutions in developing countries (Udegbe, 2012). This is due to the development of Information and communication technology (ICT) particularly internet-based technology (Ali, 2011). Because of the use of ICT particularly the internet, ODL is described using the terms e-learning (electronic learning) and online learning (Moore \& Kearsley, 2005).

ODL took root in many countries as a means to resolve political compulsions and also to fulfil the aspirations of different sections of the people who had missed educational opportunities, not as a matter of individual choice but as compulsions of social and cultural contexts (Rao, 2011). ODL offers flexibility and teaching approaches that are centered on the student with regard to content, time, place, pace of learning, method of instruction and nature of assessment (Wei, 2010). ODL is characterized by learners' freedom of selection of what, when and where to learn (Sharma \& Gupta, 2012). Thus, the objective of ODL is to enhance the opportunities that support education for all and life-long learning (Ofoegbu, 2009).

Unlike in conventional educational institutions, teachers and the students are isolated by distance and time in ODL (Udegbe, 2012). Due to distance and lack of contact with students in ODL, there has been a higher failure rate and low graduation rate. This has led government to exert strong pressure on ODL educational institution to improve student success (Subotzky \& Prinsloo, 2011). As a result, ODL institutions provide students support (Wei, 2010). University such as UNISA have provided libraries, computer labs, internet-based support, free e-mail, online tutors and learning centres for face-to-face tutorial in order to support students. Although discontinued in 2011, UNISA had a contact centre through which students can call for help with their study related matters.

Bouras et al. (1998) define ODL as the process of learning with the use of Telematics that is the combination of 
telecommunication, information and multimedia technology and its services (Bouras et al. 1998). This definition is limiting ODL to ICT and is therefore not inclusive of what ODL is all about. Moore and Tait (2002) define ODL as approaches that focus on opening access to education and training provision, freeing learners from the constraints of time and place, and offering flexible learning opportunities to individuals and groups of learners. Although it does not mention ICT, this definition is comprehensive. Kurtz, Amichai-Hamburger and Kantor (2009) define ODL as an interactive teaching-learning process, in which at least part of it is done online by means of text/audio/video. This definition does not differentiate ODL institutions and traditional/conventional institutions because it does not address the distance between teachers and learners. Having considered these definitions and for the purpose of this study, ODL is defined as a system that offer education without boundaries of knowledge content, time and place through the help of ICT and provide learner support to ensure learner success.

UNISA is the largest ODL institution in Africa and the longest standing dedicated distance education university in the world. UNISA enrols nearly one-third of all South African students. Founded in 1873 as the University of the Cape of Good Hope, the institution became the first public university in the world to teach exclusively by means of distance education in 1946. Throughout the years, UNISA was the only university in South Africa to have provided all people with access to education, irrespective of race, colour or creed. UNISA offer an unparalleled range of study choices, ranging from short courses and certificate programmes to three and four year degrees and diplomas, to over 350000 students almost every year (http://www.unisa.ac.za/Default.asp?Cmd=ViewContent\&ContentID=17765).

According to Pityana (2009), UNISA has the highest foreign student enrolment figures in Africa and provides its teaching and learning and administrative services worldwide. He further indicate that UNISA has a direct impact on higher education in South Africa, and increasingly, on the Continent, and its successes or failures will be reflected similarly. Pityana (2009) acknowledges that UNISA as an ODL institution has challenge which is to endeavour not only to ensure access and affordability but to address national anxieties about drop-out, success and throughput rates. Scott, Yeld and Hendry (2007) found that at UNISA only $30 \%$ of the 2000 first-time student cohort had graduated within five years. Moreover, with a further $14 \%$ still registered, $56 \%$ of the cohort had therefore discontinued their studies. UNISA is experiencing rapid increase in enrolment and causes operational problems such as late deliveries of study materials (Subotzky \& Prinsloo, 2011).

\section{Research Method}

All students (330) registered for the EL course in administrative management were contacted to participate in the survey. Students were requested to attach the completed questionnaire to their project and submit them all together. Those who failed to attach the questionnaire to their project scanned and e-mail or faxed the questionnaire to the lecturer. Of the 330 students, only 270 were admitted to the examination allowing them an opportunity to submit their project. Only 97 usable questionnaires were received from the students.

A questionnaire was designed to establish employability skills acquired during the course. The questionnaire also established the biographic data of the students such as gender, race, age, and marital status. The instrument also established the industries in which the students were placed. Moreover, the instrument also established the relevancy of the EL project to the work environment.

The instrument measured employability by establishing the employability skills acquired during the course. Employability skills identified by Wilton (2011) were used as a base to establish employability. Wilton (2011) identified the following employability skills for business and management graduates: Written communication; ability to work in teams; research skills; basic computer literacy; spoken communication; problem-solving skills; numeracy skills; management skills; leadership skills; creativity; entrepreneurial skills; and advanced IT or software skills. The section on employability skills was made up of 13 items. A 5-point Likert Scale ranging from "Strongly Disagree" to "Strongly Agree" was used to establish the acquisition of employability skills from the course.

To ensure validity of the instrument, a pilot study was conducted. The pilot study helped in the refinement of the instrument to ensure that it measure what it is supposed to measure. The pilot study also helped to ensure that questions were easily understood by the respondent.

A questionnaire was posted to all students registered for the course. They were asked to complete the questionnaire and attach it to the portfolio of evidence and submit them all together in due course. E-mails and SMSs were sent to the students to remind them about completing the questionnaire. Upon receiving the questionnaires, verification, coding and capturing was done. The captured data was sent to the statistician for analysis. Descriptive statistics were used to analyse the collected data. Reliability analysis was also conducted to establish the reliability of the research. 


\section{Research Results}

Of the 97 students, $19.6 \%$ were male and $80.4 \%$ were female. The racial groups were represented as follows: African (69.1\%); Asian (3.1\%); Coloured (9.3\%); and White (18.6\%). The students were in the following age groups: 20-29 years (36.1\%), 30-39 years (44.3\%) and 40 years or older (19.6\%). Of the 97 students, 51.5\% were single, $43.3 \%$ married and $5.2 \%$ divorced. Students who were employed before the start of the project were $77.3 \%$ and $22.7 \%$ had to find a placement.

Only students who were placed in the work environment and completed their portfolio were to return the questionnaire. $38.1 \%$ of the students found the placement themselves; $4.1 \%$ were assisted by the university to find placement; $3.1 \%$ were placed in a family business; $4.1 \%$ were employed at the university; and $50.5 \%$ got placed in other businesses. Of the 97 students, $56.7 \%$ indicated that two months was long enough for the completion of the project whereas $43.3 \%$ indicated that it was not. Those who indicated that two month was not long enough gave the following summarised reasons:

- It requires time to adjust to the work environment (4.8\%)

- It is difficult to complete the project if you are registered for many other modules (2.4\%)

- There is so much to be learned (83.3\%)

- Mentors are not always available to assist because of their tight schedule (9.5\%)

When asked what the suitable time frame in months should be, $6.2 \%$ of the students chose three months; $19.6 \%$ chose four months; $1 \%$ chose five months; 10.3 chose six months; $2.1 \%$ chose seven months; and the remaining 60.8 happy with two months. Students were placed in the following industries: public service (11.3\%); transport, storage and communication (8\%); educational services (8.2\%); agriculture, forestry and fishing (7.2\%); financing, insurance, real estate and business services (7.2\%); medical, dental, other health and veterinary and business services (7.2\%); social and related community services (7.2\%); mining and quarrying (5.2\%); eelectricity, gas and water (4.1\%); law (3.1\%); agencies and other services (3.1\%); Food, beverages and tobacco (2.1\%); Paper, printing and publishing (2.1\%); machinery and related items (2.1\%); manufacturing (2.1\%); construction (2.1\%); retail trade (2.1\%); safety and security (1\%); office automation (1\%); IT services (1\%); government agency (1\%); equipment programme sector (1\%); laundry (1\%); commercial and industrial; auditing (1\%); wood, wood products and furniture (1\%); chemicals, and chemical, rubber and plastic products (1\%); catering and accommodation (1\%); and long-term insurers (1\%).

As it pertain to the project content; $81.4 \%$ agreed that the project covers everything about the current administrative practice; $89.6 \%$ agreed that the project deals with relevant administrative duties; $90.7 \%$ agreed that the project prepares students for the work environment; $82.4 \%$ indicated that the project was challenging; $85.6 \%$ indicated that the project makes them want to know about the organisation they were place in; $53.6 \%$ indicated that the project is relevant to the workplace; $68.1 \%$ indicated that the project covers things that are happening in the workplace; and $61.8 \%$ indicated that the project should not be changed. The following additional comments were provided concerning the project content:

- It changes mindsets;

- It covers all relevant administrative skills;

- It develops skills such as communication, team work; sending of e-mails and report writing, punctuality and attendance, and develops awareness to the workplace culture;

- It gives an opportunity to get out of the comfort zone;

- It helps students to think critically;

- It helps with the application of theory;

- It prepares students for the work environment;

- It's difficult to find placement;

- It's difficult to get information from larger organisation;

- So Some contents are not relevant to the work environment me aspects were complicated and most employees could not tackle them;

- Students are exposed to the work environment and working conditions;

- The content of the project must relate to what is happening in the work environment;

- The organisation does not hire tools and equipments and it makes it difficult to deal with activities;

- The student was employed due to EL;

- The EL is spot on and prepares students accordingly; and 
- University must align the course content with what companies are doing.

The employability skills identified by Wilton (2011) were used to establish whether the course made the students employable. Students were asked to indicate whether they agree or disagree that the course provides them with these skills. Table 1 reveals the agreement to the provision of the employability skills. On average $85 \%$ of the students agreed that the course provide them with employability skills. It is worth noting that $96.9 \%$ of the students indicated that the course provided them with spoken communication skill. This is followed by basic computer literacy $(94.9 \%)$ and written communication (90.6). It is also worth noting that Advanced IT or software skills had the lowest students' agreement.

Table 1: Frequency of Agreements to Gaining Employability skills

\begin{tabular}{|l|c|c|}
\hline Employability skills & Frequency & Percentage \\
\hline Spoken communication & 94 & 96.9 \\
\hline Basic computer literacy & 92 & 94.9 \\
\hline Written communication & 88 & 90.7 \\
\hline Problem-solving skills & 87 & 89.6 \\
\hline Creativity & 84 & 86.6 \\
\hline Ability to work in teams & 83 & 85.6 \\
\hline Research skills & 83 & 85.6 \\
\hline Management skills & 83 & 85.6 \\
\hline Numeracy skills & 80 & 82.5 \\
\hline Leadership skills & 79 & 81.4 \\
\hline Entrepreneurial skills & 70 & 72.2 \\
\hline Advanced IT or software skills & 67 & 69.0 \\
\hline
\end{tabular}

Table 2 below shows the calculated mean and standard deviation per employability skill. The average mean and standard deviation were calculated to be 4.28 and 0.811 respectively. An average standard deviation of 0.811 indicates that there was less spread of responses to the employability skills. The average mean of 4.28 indicate that most of the students agreed that the course provide them with employability skills.

Table 2: Mean and standard deviation of employability skills

\begin{tabular}{|l|c|c|c|}
\hline \multicolumn{3}{|c|}{ Item Statistics } & \multicolumn{3}{c|}{ Std. Deviation } & $\mathrm{N}$ \\
\hline Written communication & Mean & .656 & 97 \\
Ability to work in teams & 4.40 & .826 & 97 \\
Research skills & 4.28 & .978 & 97 \\
Basic computer literacy & 4.21 & .596 & 97 \\
Spoken communication & 4.54 & .561 & 97 \\
Problem-solving skills & 4.53 & .702 & 97 \\
Numeracy skills & 4.40 & .833 & 97 \\
Management skills & 4.26 & .854 & 97 \\
Leadership skills & 4.25 & .874 & 97 \\
Creativity & 4.16 & .787 & 97 \\
Entrepreneurial skills & 4.28 & .982 & 97 \\
Advanced IT or software skills & 4.07 & 1.083 & 97 \\
\hline
\end{tabular}

The following summarised additional comments concerning employability skills were provided by the students:

- I gained phone answering skills, listening skills; telecommunication skills; ability to operate office equipment; cooperation; and ability to perform administrative tasks

- I gained coordination skills;

- I learned how to take minutes, conflict management and working under pressure;

- I learned office etiquette, customer care skills and meeting deadline;

- I was exposed to labour law, conditions of services and employment equity;

- I learned filling skills and computer system skills;

- I learned photo copying, time management and record keeping; 
- I learned interpersonal skills; negotiation skills; writing skills; and mentorship skills;

- I learned advanced accounting skills;

- I learned typing skills;

- I learned working with people;

- I learned organising meeting and handling difficult suppliers;

- I learned analysis skills;

- I learned research skills;

- I learned customer care skills;

- I learned the ability to work under pressure, adoption to the work environment; and giving inputs in meetings;

- I learned about wages and salaries information and labour relations acts.

In trying to establish correlation between demographics and employability skills, the following strong positive linear correlations were established:

Pearson's $r$ for written communication and marital status was 0.746 . Thus, there was a strong positive linear association between these two variables. The cross-tabulation showed that 44 out of 50 (88\%) single students, 39 out of 42 (93\%) married students and 5 out $5(100 \%)$ divorced students agreed that the course provided them with communication skills. Thus, almost all married and divorced students gained communication skills from the course.

There was a strong positive linear association between ability to work in teams and marital status. Pearson's $r$ for these variables was 0.750 . The cross-tabulation revealed that 43 out of $50(86 \%)$ single students, 36 out of $42(86 \%)$ married students and 4 out of $5(80 \%)$ divorced indicated that they gained the ability to work in teams. Thus almost all single and married students gained the ability to work in teams from the course.

The Pearson's $r$ for research skills and marital status was 0.719 . The cross-tabulation showed that 40 out of 50 (80\%) single student, 38 out of $42(91 \%)$ married students and 5 out of $5(100 \%)$ divorced students acquired research skills. Thus almost all married and divorced students acquired research skills regardless from the course.

There was a very strong positive linear relationship between problem solving skills and marital status. The Pearson's $r$ for these variables was 0.825 . The cross-tabulation showed that 44 out of $50(88 \%)$ single students, 38 out of 42 (91\%) married students and 5 out 5 (100\%) divorced students acquired problem solving skills. Thus, majority of married and divorced students gained problem-solving skills from the course.

The Pearson's $r$ for variables racial group and numeracy skills was 0.936 . Thus there was a very strong positive linear relationship between these two variables. The cross-tabulation showed that 53 out of 67 (79\%) African students, 3 out of $3(100 \%)$ Asian students, 8 out of 9 (89\%) Coloured students and 16 out of 18 (89\%) White students acquired numeracy skills. Thus, majority of coloured and white students acquired numeracy skills from the course.

There was a very strong positive linear association between numeracy skills and marital status. The Pearson's $r$ for these two variables was 0.928 . The cross-tabulation showed that 39 out of $50(78 \%)$ single students, 37 out of 42 (88\%) married students and 4 out 5 (80\%) divorced students acquired numeracy skills. Thus, most married students acquired numeracy skills from the course.

The Pearson's $r$ for the variables management skills and gender was 0.798 . There was therefore a strong positive linear relationship between management skills and gender. The cross-tabulation showed that 16 out of 19 (84\%) male and 67 out of 78 (86\%) female students gained management skills. Thus, a greater percentage of female students gained management skills from the course.

There was a strong positive linear association between management skills and age group. The Pearson's $r$ for these variables was 0.769 . The cross-tabulation showed that 28 out of $35(80 \%)$ students of age group $20-29$ years, 38 out of $43(88 \%)$ of students of age group 30-39 years and 17 out of $19(90 \%)$ students of age group 40 years or older gained management skills from the course. Thus, a greater percentage of students who were 40 years and older acquired management skills from the course.

The Pearson's $r$ for variables management skills and marital status was 0.791 . There was therefore a strong positive linear relationship between these variables. The cross-tabulation showed that 41 out of $50(82 \%)$ single students, 37 out of 42 (88\%) married students and 5 out of $5(100 \%)$ divorced students acquired management skills. Thus, most married and divorced students acquired management skills from the course.

There was a very strong positive linear relationship between age group and advance IT or software skills. The Pearson's $r$ for these variables was 0.910 . The cross-tabulation revealed that 25 out of $35(71 \%)$ students of age group 20-29 years, 30 out of $43(70 \%)$ of students of age group 30-39 years and 12 out of 19 (63\%) students of age group 40 years or older gained management skills from the course. Thus, a greater percentage of students in age group 30-39 years acquired management skills from the course. 


\section{Discussion}

Educational institutions around the world are implementing courses with EL. However, they must ensure that the courses attain that which they are intended to do. This can be done by continuous evaluation of these courses. The evaluation of the administrative practice course offered at UNISA reveals that the course covers all the current practices in administrative management. The findings also show that this EL course prepares students for the work environment.

The findings indicate that the majority of the students were female; African; between the age of 30 and 39 years; single; and employed. This confirms the continual trend of fewer men in administrative positions. Most administrative positions in organisations are occupied by women. The findings of this research indicate that the trend is not going to change anytime soon. Also, there are more Africans interested in administrative management than other races. This also confirms the current trend in the labour market of most administrators being African. Moreover, most students were middle age, single and employed.

The majority of the students indicated that two months in the work environment was enough to complete the project. The majority of the students who indicated that two months was not enough indicated that there is too much to be learned. Some students indicated that workplace mentors are not always available making it difficult for them to complete the project in two months. It is worth noting that most of the students were placed in the public service industry. Therefore educational institution must establish a good relationship with the public services for future students work placement.

When asked if the course offered them employability skills, majority of the students indicated that EL provided them with employability skills. Verbal or spoken communication, basic computer literacy and written communication were on top of the list of employability skills. These three skills are basic requirements for most administrative positions. The findings indicate that EL has a great influence on employability. On average $85 \%$ of the students agreed that the course provided them with employability skills. The findings reveal that some students got employed because of the course. This signifies that indeed administrative practice makes students employable.

The findings of the research also reveal that marital status has a significant positive influence on employability skills, namely written communication, ability to work in teams, problem-solving skills, numeracy skills and management skills. The findings indicate that married students tend to acquire more of these skills than students of other marital statuses. The findings also show that age group has a significant positive influence on management skills and advanced IT or software skills. The findings show that students who are 30-39 years acquired advanced IT or software skills whiles students who were 40 years or older acquired management skills. The findings also reveal that coloureds and white students acquired numeracy skills from the course. Moreover, the findings reveal that most female students gained management skills than male students.

\section{Conclusion}

While the supply of B\&M graduates to the labour market has grown significantly (Wilton; 2011), there is a gap between the skills they acquired and the skills required by the employers (Wickramasinghe \& Perera; 2010). It is the responsibility of educational institutions to equip students with employability skills (Nayan, 2010). Educational institutions have realised that EL is the major contributor to employability (Yorke \& Knight, 2004). The purpose of this research was to establish the influence of a work-integrated learning course in administrative management on employability.

Administrative practice is relevant to the current administrative practice in the work environment. It prepares students for the work environment and exposes them to administrative duties and responsibilities. Although some students complained about a shorter period at the work place, majority of the students found two months enough to complete their project. Some students got employed because of participating in the course. Moreover, majority of the students indicated that the course provided them with employability skills identified by Wilton (2011).

Marital status has a significant influence in employability skills. Married and divorced students acquired most employability skills than students of other statuses. Therefore, single students must be assisted for them to be able to acquire most employability skills. Also, age has a significant influence on management skills and advanced IT or software skills. Therefore, younger students must be assisted in order for them to gain these skills. Moreover, gender has a significant influence on management skills. Most female students acquired management skills than males.

It is therefore clear from the findings that administrative practice have a positive influence on employability. The findings concur with the current literature that EL provides students with employability skills. Therefore education institutions, particularly open distance learning ones must incorporate EL in their business management courses.

This research was only limited to those students who managed to find placement. A follow up study should be conducted to establish whether those students who were not employed have fund employment. Moreover, a further study 
should be conducted to establish whether the students who were employed have sustained their employment.

\section{Acknowledgements}

This work is based on the research supported by the National Research Foundation. The authors would also like to acknowledge the University of South Africa (South Africa) for the funding and support without which this research would not have been possible.

\section{References}

Ali, E.A. (2011). Challenges before open and distance learning: global perspective and the experience of open university Malaysia. In International Conference cum Workshop, 7 - 9 March 2011 (pp. 1-16). Vardhaman Mahaveer Open University, Kota, Rajasthan, India.

Arrowsmith, C., Bagoly-Simo, P., Finchum, A., Oda, K. \& Pawson, E. (2011). Student employability and its implications for geography curricula and learning practices. Journal of Geography in Higher Education, 35(3), 365 - 377.

Bouras, C., Destounis, P., Garofalakis, J., Gkamas, A., Sakalis, G., Sakkopoulos, E., Tsaknakis, J. \& Tsiatsos, T. (2000). Efficient webbased open and distance learning services. Telematics and Informatics, 17(2000), 213 - 237.

Clark, J. \& White, G.W. (2010). Experiential Learning: A Definitive Edge In The Job Market. American Journal of Business Education, $3(2), 115-118$.

Cox, S. \& King, D. (2006). Skill sets: an approach to embed employability in course design. Education + Training, 48(4), 262 - 274.

Ghose, N. (2010). Enhancing Global Competitiveness Through Experiential Learning: Insights Into Successful Programming. American Journal of Business Education, 3(7), 1 - 6.

Gokuladas, V.K. (2011). Predictors of Employability of Engineering Graduates in Campus Recruitment Drives of Indian Software Services Companies. International Journal of Selection and Assessment, 19(3), 313 - 319.

Hynes, B. \& Richardson, I. (2007). Entrepreneurship education: a mechanism for engaging and exchanging with the small business sector. Education + Training, 49(8/9): 732 - 744 .

Jennings, C. \& Wargnier, J. (2010). Experiential learning - a way to develop agile minds in the knowledge economy? Development and Learning in Organizations, 24(3), $14-16$.

Kolb, D. (1984). Experiential learning: Experience as the source of learning and development. Englewood Cliffs: Prentice Hall.

Kurtz, G. Amichai-Hamburger, Y. \& Kantor, J. (2009). Psychosocial Well-Being of Israeli Students and Attitudes toward Open and Distance Learning. The International Review of Research in Open and Distance Learning, 10(2).

Little, B. (2004). Employability and work-based learning. Innovation Way, York Science Park: The Higher Education Academy.

Moore, M. \& Tait, A. (2002). Open and Distance Learning: Trends, Policy and Strategy Considerations. Paris: UNESCO.

Moore, M.G. \& Kearsley, G. (2005). Distance education: A systems view. $2^{\text {nd }}$ edition. Belmont, CA: Wadsworth.

Moore, C., Boyd, B.L., Dooley, K.E. (2010). The Effects of Experiential Learning with an Emphasis on Reflective Writing on Deep-Level Processing of Leadership Students. Journal of Leadership Education, 9(1), 36 - 52.

Nauta, A., Van Vianen, A., Van der Heijden, B., Van Dam, K. \& Willemsen, M. (2009). Understanding the factors that promote employability orientation: the impact of employability culture, career satisfaction, and role breadth self-efficacy. Journal of occupational and organisational psychology, 82(2), 233 - 251.

Nevin, T. (2001). Business skills in jail. African business, 1(1), 41 - 42.

Nilsson, S. (2010). Enhancing individual employability: the perspective of engineering graduates. Education + Training, 52(6/7), 540 551.

Ofoegbu, I.F. (2009). Female access to basic education: a case for open distance learning (ODL). Edo Journal of Counseling, 2(1), 46 57.

Pityana, N.B. (2009). Open distance learning in the developing world: trends, progress and challenges. In 23rd ICDE World Conference on Open Learning and Distance Education, 7 - 10 June 2009 (pp. 1-18). Maastricht, the Netherlands.

Procter, C. (2011). Employability and entrepreneurship embedded in professional placements in the business curriculum. Journal of Chinese entrepreneurship, 3(1), 49 - 57.

Rao, P.K. (2011). Enrolment, Success Rate and Expenditure in Open and Distance Learning - The Experience of the First Open University in India. Journal of open schooling, 2(1), 34 - 43.

Rothwell, A., Jewell, S. \& Hardie, M. (2009). Self-perceived employability: investigating the responses of post-graduates students. Journal of vocational behaviour, 75(2), 152 - 161.

Scott, I., Yeld, I. \& Hendry, J. (2007). A case for improving teaching and learning in South African higher education. Pretoria: The Council on Higher Education.

Sharma, S. \& Gupta, S. (2012). The Virtual Classroom: The Role of ICT in Open and Distance Learning. International Journal of Computer, Communication and Emerging Technology, 1(1): 8 - 12.

Smith, A.J., Collins, L.A., Hannon, P.D. (2006). Embedding new entrepreneurship programmes in UK higher education: Challenges and considerations. Education + training, 48(8/9), 555 - 567.

Subotzky, G. \& Prinsloo, P. (2011). Turning the tide: a socio-critical model and framework for improving student success in open 
distance learning at the University of South Africa. Distance Education, 32(2), 177 - 193.

Stoner, G. \& Milner, M. (2010). Embedding generic employability skills in an accounting degree: development and impediments. Accounting Education: An International Journal, 19(1), 123 - 138.

Udegbe, B. (2012). Attitudes of Prospective Human Resource Personnel towards Distance Learning Degrees. Online Journal of Distance Learning Administration, 15(1).

Van der Heijde, C. \& Van der Heijden, B. (2006). A competence-based and multidimensional operationalization and measurement of employability. Human Resource Management, 45(3), 449 - 476.

Vesper, J., Bishara, R. \& Reeves, T. (2010). A Case Study in Experiential Learning: Pharmaceutical Cold Chain Management on Wheels. Journal of continuing education in the health professions, 30(4), 229 - 236.

Vincett, P.S. \& Farlow, S. (2008). Start-a-business: an experiment in education through entrepreneurship. Journal of small business and enterprise development, 14(2), 274 - 288.

Watton, P. \& Truscott, J.B. (2006). Enhancing student employability and entrepreneurship through the environmental and natural sciences. Retrieved October 17, 2012, from http://www2.plymouth.ac.uk/science/elcet//Documents/ WBL_Employability/pdf/Enhancing_student_employability_Nov_2006.pdf

Wei, R. (2010). China's radio and TV universities: reflections on theory and practice of open and distance learning, Open Learning. The Journal of Open, Distance and e-Learning, 25(1), 45 - 56.

Wellma, N. (2010). The employability attributes required of new marketing graduates. Marketing Intelligence \& Planning, 28(7), 908 930.

Wickramasinghe, V. \& Perera, L. (2010). Graduates, university lecturers and employers perceptions towards employability skills. Education + Training, 52(3), 226 - 244.

Wilton, N. (2011). Do employability skills really matter in the UK graduate labour market? The case of business and management graduates. Work, Employment and Society, 25(1), 85 - 100.

Wittekind, A., Raeder, S., Grote, G. (2010). A longitudinal study of determinants of perceived employability. Journal of Organisational Behaviour, 31(4), 566 - 586.

Yorke, M. \& Knight, P.T. (2004). Embedding employability into the curriculum. New York: The higher education academy. 